\title{
The expression of genes involved in myometrial contractility changes during ex situ culture of pregnant human uterine smooth muscle tissue
}

\author{
Marina Ilicic ${ }^{1,2,3}$, Trent Butler ${ }^{1,2,3}$, Tamas ZAKaR ${ }^{1,2,3,4}$ and Jonathan W. PAUL ${ }^{1,2,3}$ \\ ${ }^{1}$ School of Medicine and Public Health, Faculty of Health and Medicine, University of Newcastle, \\ Callaghan, NSW 2308, Australia \\ ${ }^{2}$ Priority Research Centre for Reproductive Science, University of Newcastle, Callaghan, NSW \\ 2308, Australia \\ ${ }^{3}$ Hunter Medical Research Institute, 1 Kookaburra Circuit, New Lambton Heights, NSW 2305, \\ Australia \\ ${ }^{4}$ John Hunter Hospital, New Lambton Heights, NSW 2305, Australia
}

Submitted January 16, 2017; accepted in final from April 26, 2017

\begin{abstract}
Background: Ex situ analyses of human myometrial tissue has been used to investigate the regulation of uterine quiescence and transition to a contractile phenotype. Following concerns about the validity of cultured primary cells, we examined whether myometrial tissue undergoes culture-induced changes ex situ that may affect the validity of in vitro models. Objectives: To determine whether human myometrial tissue undergoes culture-induced changes ex situ in Estrogen receptor 1 (ESR1), Prostaglandin-endoperoxide synthase 2 (PTGS2) and Oxytocin receptor (OXTR) expression. Additionally, to determine whether culture conditions approaching the in vivo environment influence the expression of these key genes. Methods: Term non-laboring human myometrial tissues were cultured in the presence of specific treatments, including; se-

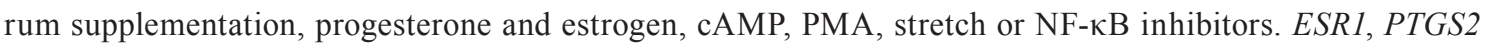
and $O X T R$ mRNA abundance after $48 \mathrm{~h}$ culture was determined using quantitative RT-PCR. Results: Myometrial tissue in culture exhibited culture-induced up-regulation of ESR1 and PTGS2 and down-regulation of OXTR mRNA expression. Progesterone prevented culture-induced increase in ESRI expression. Estrogen further up-regulated PTGS2 expression. Stretch had no direct effect, but blocked the effects of progesterone and estrogen on ESR1 and PTGS2 expression. cAMP had no effect whereas PMA further up-regulated PTGS2 expression and prevented decline of OXTR expression. Conclusion: Human myometrial tissue in culture undergoes culture-induced gene expression changes consistent with transition toward a laboring phenotype. Changes in ESR1, PTGS2 and OXTR expression could not be controlled simultaneously. Until optimal culture conditions are determined, results of in vitro experiments with myometrial tissues should be interpreted with caution.
\end{abstract}

Key words: myometrium, phenotype, transition, ESR1, OXTR, PTGS2

Corresponding author: Jonathan W. Paul, Hunter Medical Research Institute, New Lambton Heights 2305, NSW, Australia Phone: +61 40423048 Fax: +61 40420045 e-mail: Jonathan.Paul@newcastle.edu.au.

(C2017 The Japan Society of Smooth Muscle Research 


\section{Introduction}

Parturition requires that myometrial smooth muscle undergo a phenotypic transition, remaining quiescent for the majority of gestation and then transforming to a tissue capable of generating forceful, co-ordinated contractions to expel the fetus and the placenta $(1,2)$. Transformation of the myometrium from the quiescent to a contractile state necessitates the presence of estrogen prior to the onset of labor (1-5). In humans and higher primates, however, maternal estrogen levels are already high for most of pregnancy and remain elevated during parturition $(6,7)$. This has led to the concept of functional estrogen activation whereby myometrium becomes sensitive to estrogen through changes in estrogen receptor (ER) expression, encoded by the genes estrogen receptor 1 (ESR1) and estrogen receptor 2 (ESR2). Our group has reported that expression of ESR1 is low in non-laboring term myometrium and that ESR1 levels rise with the onset of labor, whilst expression of ESR 2 was barely detectable and did not change with labor $(8,9)$. This suggests that increased ESR 1 expression mediates functional estrogen activation. Furthermore, we found that U-0126, a highly selective inhibitor of mitogen-activated protein kinase kinase (MEK), blocked the ability of estrogens to stimulate the expression of the oxytocin receptor (OTR) in human myometrial samples in vitro (9). Expression of the oxytocin receptor gene (OXTR) in the myometrium increases after 37 weeks of gestation (10), which is followed by a fall in advanced labor (11-13). Furthermore, a genome-wide study found that the high OXTR mRNA abundance in term non-laboring myometrium samples decreased with labor (14). Studies using human tissues and myometriumderived cell lines have demonstrated that the binding of oxytocin to its receptor led to activation of nuclear factor kappa-light-chain-enhancer of activated B cells (NF-kB), which subsequently increased the production of prostaglandins (PGs), inflammatory chemokines and cytokines that are involved in fetal membrane remodelling, cervical ripening and myometrial activation $(15,16)$. Prostaglandin-endoperoxide synthase 2 (PTGS2) encodes a key enzyme responsible for the biosynthesis of PGs. PTGS2 mRNA abundance is low in term nonlaboring human myometrium and increases with the onset of labor $(14,17)$. Increased expression of ESR1 and PTGS2 and decreased expression of OXTR is therefore associated with transition toward a laboring phenotype. Characterizing the regulation of these key myometrial genes is essential to understanding normal human birth, as well as obstetric complications, including preterm labor.

Outside of clinical trials, researchers are primarily limited to observational studies on human pregnancy and as such rely heavily on animal models of pregnancy and in vitro studies using human cell lines and tissues. Primary myocyte cultures have been used extensively to study myometrial biology, but concerns have been raised about the lifespan of cultured primary cells (18) and their ability to remain to be representative of the tissue of origin (19-22). Incubation of tissue ex vivo as small pieces or strips may represent the in vivo phenotype more closely. Tissue strips are routinely used to analyze the effect of treatments on contractility (23-25), and have even been used to capture dynamic phosphorylation events that occur in phase with contractions $(26,27)$.

Incubating pieces and strips of myometrium has emerged a popular experimental model for interrogating myometrial biology. Both approaches involve artificial in vitro conditions and rely on the assumption that the tissue phenotype remains stable across the course of the study. Non-laboring myometrial tissue strips, however, spontaneously develop rhythmic contractions in vitro over the course of just 1-2 h, suggesting that the tissue strips may rapidly transition away from a non-contractile phenotype $(23,25,26)$. Moreover, with tissue incubation studies routinely performed for $48 \mathrm{~h}$ or more, the transition from the in vivo phenotype may be even more pronounced. The implications are potentially significant as findings made using 'non-laboring' tissue may in fact have been generated using tissue that may not be representative of the non-laboring phenotype and could respond differently to treatments. 
Experimental models of myometrium that are in a state of flux have the potential to confound the results when researchers seek to elucidate the trigger(s) for labor. Through characterizing the expression of key myometrial genes, the present study aimed to explore whether non-laboring myometrial tissue pieces and strips undergo culture-induced changes in vitro that are consistent with transition to a pro-contractile, laboring phenotype. We further aimed to identify culture conditions that could prevent or attenuate phenotypic changes thereby providing researchers with a stable platform to conduct experimental studies.

Here we report evidence suggesting that non-laboring human myometrium undergoes a culture-induced transition to a labor-like phenotype in vitro. We further report that different aspects of the non-laboring phenotype can be differentially preserved by supplementing the medium with physiological concentrations of progesterone and estrogen, applying NFKB inhibitors and by exposing the uterine muscle samples to constant stretch.

\section{Materials and Methods}

\section{Consumables and reagents}

Superscript III First Strand Synthesis System, Ultrapure Glycogen, UltraPure Agarose and Trackit 100 BP DNA ladder were purchased from Invitrogen (Carlsbad, USA). TRizol Reagent and Turbo DNA-free 50 reactions were from Ambion (Austin, USA). Alien QRT-PCR Inhibitor Alert was purchased from Integrated Sciences Pty (Sydney, Australia). (R)-MG132, BAY-11-7085 and Phorbol Myristate Acetate (PMA) were obtained from Cayman Chemical Company (Michigan, USA). 8-Bromoadenosine 3',5'-cyclic monophosphate (8-Br-cAMP), PCR primers, Progesterone and Estradiol were purchased from Sigma (St Louis, USA). The $2 \mathrm{ml} 2.8 \mathrm{~mm}$ CK28-R Ceramic Bead Kit was acquired from Bertin Technologies (Montigny-le-Bretonneux, France). L-Glutamine, Sodium Pyruvate, Gentamicin, HEPES, Dulbecco's Modified Eagle Medium (DMEM) and Charcoal Stripped Fetal Bovine Serum were obtained from Gibco (Carlsbad, USA). SYBR Green $2 \times$ Master mix was from Applied Biosystems (Carlsbad, USA).

\section{Myometrial Tissue acquisition}

These studies were approved by the Hunter and New England Area Human Research Ethics Committee and the University of Newcastle Human Ethics Committee (02/06/12/3.13). Human myometrial samples $(5 \times 5$ $\times 10 \mathrm{~mm}$ ) were obtained from the lower uterine segment during elective Caesarean section (CS) of singleton term pregnancies (38.2-39.6 weeks gestation). Patient BMI range was 18.3-38.0, and none of the patients were in-labor. The indications for elective CS were previous CS, placenta praevia, fetal distress or breach presentation. Women were excluded if they were given steroids. Following delivery of the placenta, all women immediately received 5 units of oxytocin (Syntocinon) into an intravenous line. Administration of oxytocin was part of the standard care for the prevention of postpartum hemorrhage. Myometrial biopsies were excised within 3 min after oxytocin administration. Samples were placed on ice in serum-free medium containing DMEM with high glucose, $2 \mathrm{mM}$ L-Glutamine, $1 \mathrm{mM}$ Sodium Pyruvate, $40 \mu \mathrm{g} / \mathrm{ml}$ Gentamicin and $10 \mathrm{mM}$ HEPES for the transfer to the laboratory.

\section{Myometrial tissue culture}

Approximately $100 \mathrm{mg}$ tissue from each sample was immediately snap frozen in liquid nitrogen for subsequent analysis. The remaining myometrium was dissected into approximately $2 \times 2 \times 2 \mathrm{~mm}$ pieces and washed in serum-free media. Samples were then incubated in serum-free or $5 \%(\mathrm{v} / \mathrm{v})$ charcoal stripped fetal 
bovine serum (CSS)-supplemented media in a $37{ }^{\circ} \mathrm{C}, 95 \%$ air $/ 5 \% \mathrm{CO}_{2}$ humidified incubator for $48 \mathrm{~h}$. The $5 \%$ CSS-supplemented culture media contained DMEM with high glucose, 5\% CSS, $2 \mathrm{mM} \mathrm{L-Glutamine,} 1 \mathrm{mM}$ Sodium Pyruvate, $40 \mu \mathrm{g} / \mathrm{ml}$ Gentamicin and $10 \mathrm{mM}$ HEPES. To determine the effects of steroids, myometrial samples were incubated in 5\% CSS-containing media with physiological concentrations of progesterone (P4; $500 \mathrm{nM}$ ) and/or estradiol (E2; $400 \mathrm{nM})(4)$ in a $37{ }^{\circ} \mathrm{C}, 95 \%$ air $/ 5 \% \mathrm{CO}_{2}$ humidified incubator for $48 \mathrm{~h}$. To determine the effect of stretch, myometrial tissue strips $(2 \times 2 \times 10 \mathrm{~mm})$ were cultured in $5 \%$ CSS-containing media for $48 \mathrm{~h}$ in a $37^{\circ} \mathrm{C}, 95 \%$ air $/ 5 \% \mathrm{CO}_{2}$ humidified incubator whilst being subjected to 0,1 or $3 \mathrm{~g}$ of constant stretch $\left(0,2.45\right.$ or $7.35 \mathrm{kN} / \mathrm{m}^{2}$, respectively). Constant stretch was applied by using nylon thread to attach stainless steel weights to the ends of strips and then suspending the strips in $30 \mathrm{ml}$ of culture media in $50 \mathrm{ml}$ tubes (strips subjected to $0 \mathrm{~g}$ only were tied at one end). To determine the effect of stretch and steroids, myometrial strips were cultured in 5\% CSS-containing media with $500 \mathrm{nM} \mathrm{P} 4$ and $400 \mathrm{nM}$ E2 for $48 \mathrm{~h}$ in a $37{ }^{\circ} \mathrm{C}, 95 \%$ air $/ 5 \% \mathrm{CO}_{2}$ humidified incubator whilst being subjected to 0,1 or $3 \mathrm{~g}$ of stretch. To determine the effects of the signalling pathways involved in myometrial relaxation and contraction, myometrial pieces were incubated for $48 \mathrm{~h}$ a $37{ }^{\circ} \mathrm{C}, 95 \%$ air $/ 5 \% \mathrm{CO}_{2}$ in $5 \%$ CSS-containing media supplemented with the cAMP analogue 8- $\mathrm{Br}$ cAMP $(250 \mu \mathrm{M})$, or PMA $(0.1,1.0 \mu \mathrm{M})$, or the NF-kB inhibitors MG-132 $(2.0,5.0,10.0 \mu \mathrm{M})$ and BAY-11-7085 $(2.0,5.0,10.0 \mu \mathrm{M})$ individually or in combination $(10.0 \mu \mathrm{M}$ MG-132 $+10.0 \mu \mathrm{M}$ BAY-11-7085). Vehicle was DMSO (0.1\%). Following each incubation, the tissue pieces or strips were snap frozen using liquid nitrogen and stored at $-80{ }^{\circ} \mathrm{C}$ for subsequent analyses.

\section{RNA extraction, reverse transcription and real-time quantitative PCR}

RNA was extracted using TRizol Reagent (Ambion, USA) according to the manufacture's protocol. Homogenization of tissue in TRizol Reagent was performed using a Precellys24 homogenizer (Bertin Instruments, France). Following extraction, RNA samples were purified using the TURBO DNA-free kit (Ambion, USA). An ND-1000 spectrophotometer (NanoDrop Technologies, Inc., USA) was used to measure RNA concentration (absorbance at 260 and $280 \mathrm{~nm}$ ) and purity. RNA integrity was checked by agarose gel electrophoresis. Each RNA sample ( $0.5 \mu \mathrm{g}$ of total RNA) was spiked with $0.5 \times 10^{7}$ copies of Alien RNA (Integrated Sciences Pty, Australia) and reverse-transcribed using the SuperScript III First-Strand Synthesis System with random hexamer primers (Invitrogen, USA). Quantitative real-time PCR was performed using an ABI 7500 Sequence Detector (Applied Biosystem, USA). No-reverse transcription (no-RT) negative controls were prepared for each sample. The final volume of each PCR reaction was $20 \mu$ l, containing $10 \mu 1$ of $2 \times$ SYBR Green PCR Master Mix (Applied Biosystems, USA), master mix cDNA template (corresponding to $10 \mathrm{ng}$ of reverse transcribed RNA), target cDNA-specific forward and reverse primers, and MilliQ water. For the reference gene (Alien primer), the final volume was also $20 \mu \mathrm{l}$ with $1.0 \mu \mathrm{l}$ of $2.5 \mu \mathrm{M}$ of Alien Primer Mix, $10 \mu \mathrm{l}$ of $2 \times$ SYBR Green PCR and the same amount of cDNA as the target genes and MilliQ water. No-template control samples (NTCs) were included in each PCR plate to detect any contamination and primer-dimers. PCR primers were designed using Primer Express and are shown in the Table 1.

\section{Data and statistical analysis}

All mRNA abundance data were expressed relative to the Alien reference RNA. The relative mRNA abundance was calculated using the delta $\mathrm{Ct}(\Delta \mathrm{Ct})$ method (28). All mRNA relative abundance values were checked for normal distribution using Shapiro-Wilk normality test and if data was not normally distributed, then it was logarithmically transformed to approach normal distribution. Statistical analyses were conducted with GraphPad Prism software (San Diego, USA). Graphical data are presented as mean \pm S.E.M. For compari- 
Table 1. cDNA primer sequences - ESR1, PTGS2 and $O X T R$

\begin{tabular}{llcc}
\hline Primer & \multicolumn{1}{c}{ Primer sequence (5'-3') } & Amplicon size & GenBank \# \\
\hline \multirow{2}{*}{ ESR1 } & F: TGAAAGGTGGGATACGAAAAGAC & 66 & NM_000125.3 \\
& R: CATCTCTCTGGCGCTTGTGTT & & \\
\hline PTGS2 & F: ATGTTCCACCCGCAGTACAGA & 73 & NM_000916.3 \\
& R: CAGCATAAAGCGTTTGCGGTA & & \\
\hline \multirow{2}{*}{ OXTR } & F: CTGGACGCCTTTCTTCTTCGT & 101 & NM_000963 \\
& R: GAAGGCCGAGGCTTCCTT & & \\
\hline
\end{tabular}

ESR1, Estrogen Receptor; OXTR, Oxytocin Receptor; PTGS2, Prostaglandin-endoperoxide synthase 2 .
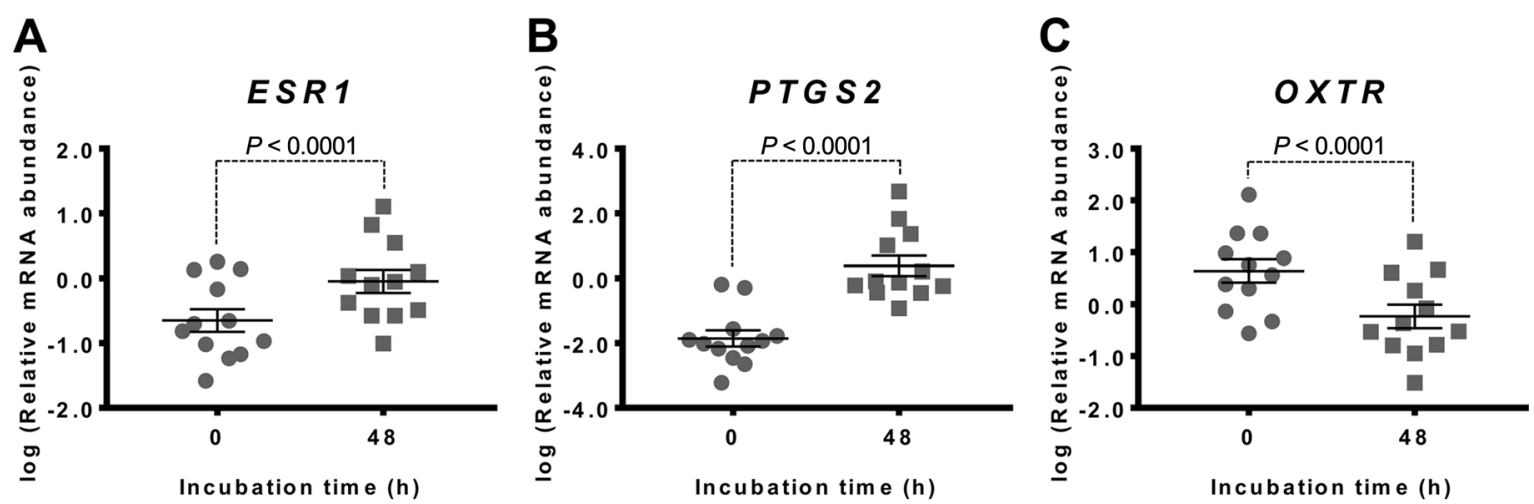

Fig. 1. Culture-induced changes in myometrial expression of ESR1, PTGS2 and OXTR mRNAs following $48 \mathrm{~h}$ culture. Relative mRNA abundance of ESR1, PTGS2 and OXTR was measured in term non-laboring myometrial tissue samples immediately after biopsy $(0 \mathrm{~h})$ as well as following $48 \mathrm{~h}$ incubation $(n=12)$, and expressed relative to Alien reference. (A) ESR1 mRNA abundance. (B) PTGS2 mRNA abundance. (C) OXTR mRNA abundance. Data was logarithmically transformed to approach normal distribution (Shapiro-Wilk normality test) then analysed by paired t-test. Data are mean \pm S.E.M.

son between two groups, Student's $t$ test was used. For multiple comparisons a one-way analysis of variance (ANOVA) followed by post-hoc test of Dunnett multiple comparisons was used. $P$-values $\leq 0.05$ were considered statistically significant.

\section{Results}

\section{Gene expression changes in myometrium during $48 \mathrm{~h}$ of culture}

Myometrial tissue samples were incubated for $48 \mathrm{~h}$ in serum-free media to determine gene expression changes that the tissue undergoes upon being removed from the in vivo environment and cultured in vitro. There was a statistically significant increase in mRNA abundance for ESR1 $(P<0.0001)$ and $P T G S 2(P<0.0001)$ (Fig. 1A and B), whilst OXTR mRNA abundance significantly decreased $(P<0.0001)$ (Fig. 1C). ESR2 mRNA abundance was detected at extremely low levels in fresh tissue, and remained low and relatively unchanged following $48 \mathrm{~h}$ incubation (not shown).

\section{Serum-free media versus 5\% CSS-containing media}

Having observed culture-induced changes in the expression of ESR1, PTGS2 and OXTR mRNAs, we examined whether the presence of $5 \%$ CSS, often included in myometrial culture media (29), affected the phe- 
A

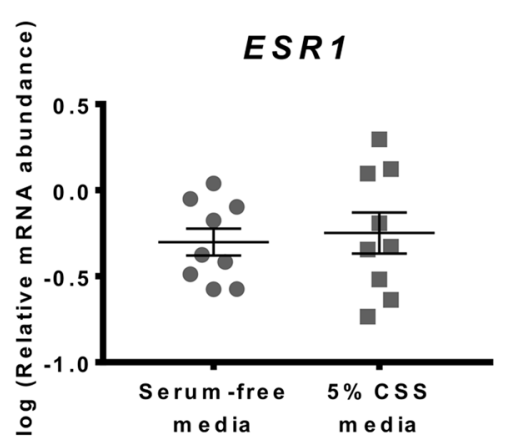

B

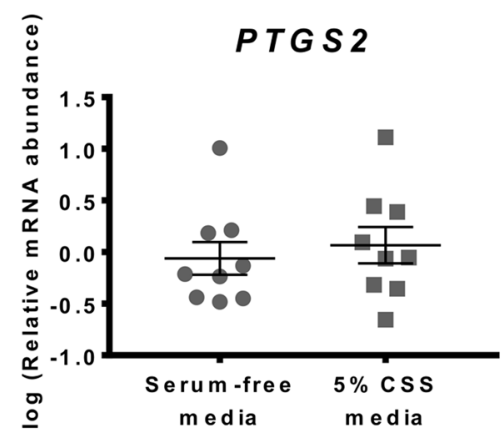

C

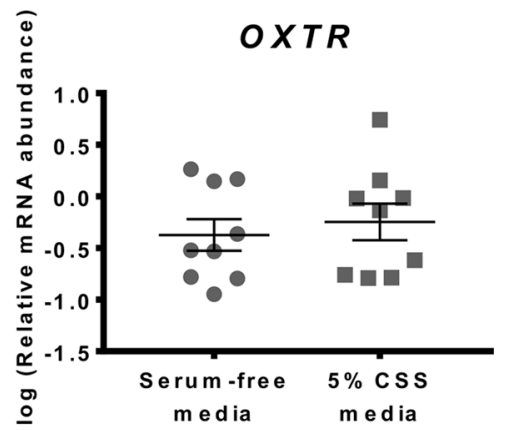

Fig. 2. Effect of serum on culture-induced changes in ESR1, PTGS2 and OXTR mRNA levels in vitro. Relative mRNA abundance of ESR1, PTGS2 and OXTR was measured in term non-laboring myometrial tissue samples following $48 \mathrm{~h}$ incubation in serum-free media or media supplemented with $5 \%$ CSS $(n=9)$, and expressed relative to Alien reference. (A) ESR1 mRNA abundance. (B) PTGS2 mRNA abundance. (C) OXTR mRNA abundance. Data was logarithmically transformed to approach normal distribution (Shapiro-Wilk normality test) then analysed by paired t-test. Data are mean \pm S.E.M.

A

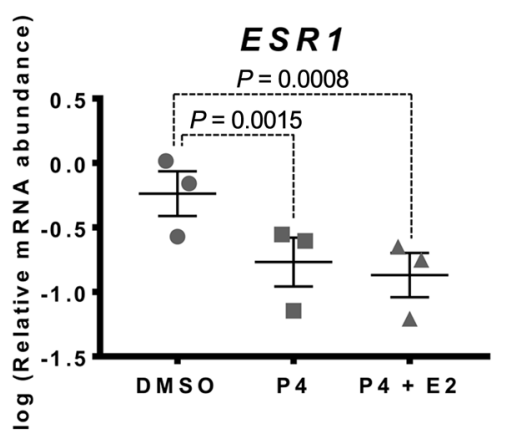

B

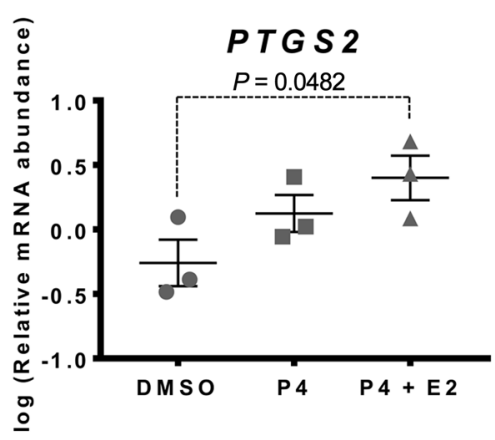

C

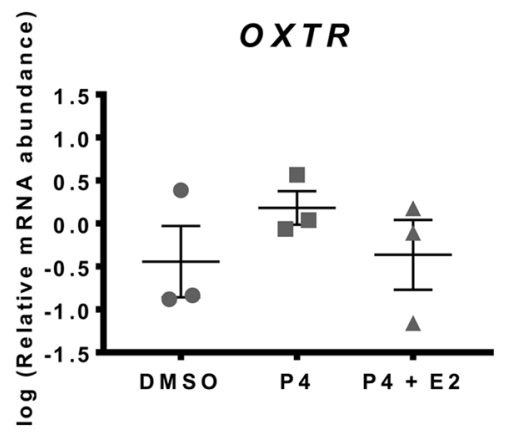

Fig. 3. Effect of steroids on culture-induced changes in ESR1, PTGS2 and OXTR mRNAs in vitro. Relative mRNA abundance of ESR1, PTGS2 and OXTR was measured in term non-laboring myometrial tissue samples following $48 \mathrm{~h}$ incubation in the presence of $500 \mathrm{nM}$ progesterone (P4) or $500 \mathrm{nM} \mathrm{P} 4+400 \mathrm{nM}$ estradiol (E2) ( $n=3$ ), and expressed relative to Alien reference. (A) ESR1 mRNA abundance. (B) PTGS2 mRNA abundance. (C) OXTR mRNA abundance. Data were logarithmically transformed to approach normal distribution (Shapiro-Wilk normality test) then compared by 1-way ANOVA with multiple comparisons (Dunnett). Data are mean \pm S.E.M.

notypic change of myometrium in vitro. Following $48 \mathrm{~h}$ incubation, there was no significant difference in ESR 1 mRNA abundance between serum-free media and 5\% CSS media (Fig. 2A). Similarly, the presence or absence of 5\% CSS in media had no effect on culture-induced change of PTGS2 mRNA abundance (Fig. 2B) or OXTR mRNA abundance (Fig. 2C) following $48 \mathrm{~h}$ incubation.

\section{The effect of steroids}

Relative abundance of ESR1, PTGS2 and OXTR mRNA was measured in myometrial tissues incubated for $48 \mathrm{~h}$ in the presence of $500 \mathrm{nM}$ P4 or $500 \mathrm{nM} \mathrm{P} 4+400 \mathrm{nM} \mathrm{E2}$, which are hormone concentrations in term maternal plasma (4).

A statistically significant decrease in ESR1 mRNA abundance was observed between DMSO- and P4treated tissue after $48 \mathrm{~h}(P=0.0015)$, indicating that supplementing media with $500 \mathrm{nM}$ P4 blocked the cultureinduced increase in ESR1 mRNA abundance compared to fresh tissue (Fig. 3A). The combination of $500 \mathrm{nM}$ 
A

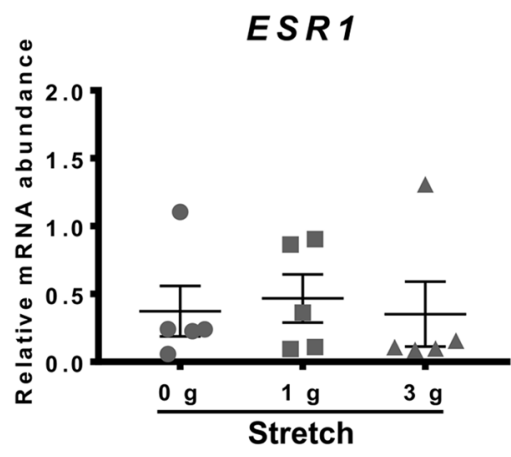

C
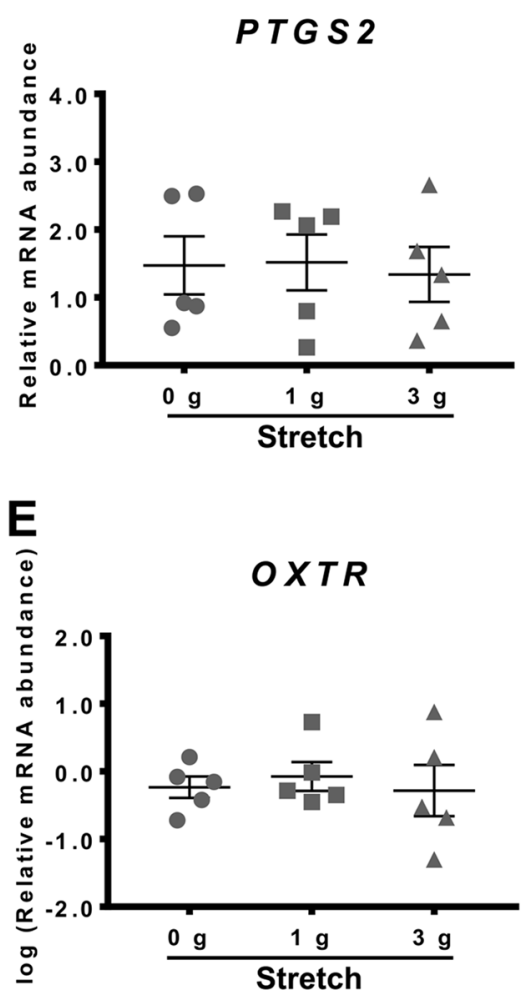

B

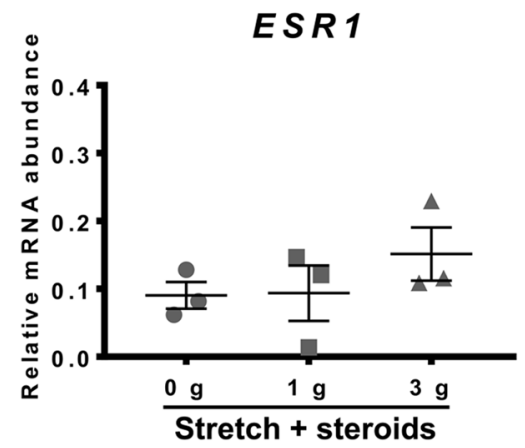

PT G S 2

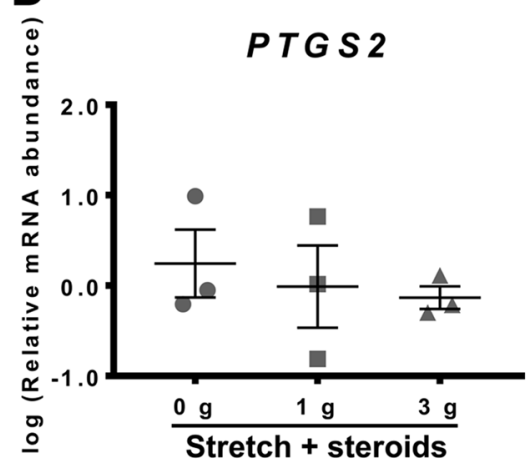

$\mathbf{F}$

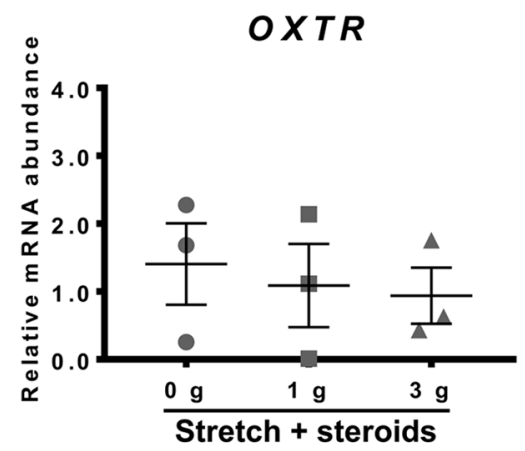

Fig. 4. Effect of stretch in the absence or presence of steroids on culture-induced changes in ESR1, PTGS2 and OXTR mRNA levels in vitro. Relative mRNA abundance of ESR1, PTGS2 and OXTR was measured in term non-laboring myometrial strips whilst applying 0,1 and $3 \mathrm{~g}$ of stretch for $48 \mathrm{~h}(n=5)$, as well as in presence of steroids (500 nM P4 $400 \mathrm{nM} \mathrm{E2)} \mathrm{whilst} \mathrm{applying} 0,1$ and $3 \mathrm{~g}$ of stretch for $48 \mathrm{~h}(\mathrm{n}=3)$, and expressed relative to Alien reference. (A) Effect of stretch on ESR1 mRNA abundance. (B) Effect of stretch and steroids on ESR1 mRNA abundance. (C) Effect of stretch on PTGS2 mRNA abundance. (D) Effect of stretch and steroids on PTGS2 mRNA abundance. (E) Effect of stretch on OXTR mRNA abundance. (F) Effect of stretch and steroids on OXTR mRNA abundance. Data was checked for normality (Shapiro-Wilk normality test) and if necessary was logarithmically transformed to approach normal distribution (Shapiro-Wilk normality test). Data was analysed using 1-way ANOVA with multiple comparisons (Dunnett). Data are mean \pm S.E.M.

$\mathrm{P} 4+400 \mathrm{nM}$ E2 had no further effect as the $500 \mathrm{nM} \mathrm{P} 4+400 \mathrm{nM}$ E2 treatment significantly reduced mRNA levels at $48 \mathrm{~h}$ relative to vehicle treatment $(P=0.0008)$, but not relative to $\mathrm{P} 4$ treatment alone (Fig. $3 \mathrm{~A})$.

Supplementing media with $500 \mathrm{nM}$ P4 had no statistically significant effect on PTGS2 mRNA abundance relative to the vehicle (Fig. 3B). Supplementing media with $500 \mathrm{nM} \mathrm{P4}+400 \mathrm{nM}$ E2, however, significantly 
increased PTGS2 mRNA abundance at $48 \mathrm{~h}$ relative to the vehicle $(P=0.0482)$, indicating that $\mathrm{P} 4+\mathrm{E} 2$ in combination exacerbated the up-regulation of PTGS2 expression compared to the fresh tissue (Fig. 3B).

Supplementing media with $500 \mathrm{nM}$ P4 alone, or $500 \mathrm{nM} \mathrm{P} 4+400 \mathrm{nM}$ E2, had no effect on the cultureinduced change in OXTR mRNA abundance (Fig. 3C).

\section{The effect of stretch on human myometrial gene expression in vitro}

Myometrial tissue strips were subjected to 0,1 or $3 \mathrm{~g}$ of stretch $\left(0,2.45\right.$ or $7.35 \mathrm{kN} / \mathrm{m}^{2}$, respectively) for $48 \mathrm{~h}$ in absence or presence of steroids (500 nM P4 + $400 \mathrm{nM} \mathrm{E2)}$ ) to determine whether applying stretch to the muscle influenced the culture-induced changes in ESR1, PTGS2 or OXTR mRNA levels in vitro.

As seen in Fig. 4A, 0-3 g stretch had no effect on ESR1 expression in the tissue strips. Interestingly, stretch in the presence of $500 \mathrm{nM}$ P4 $+400 \mathrm{nM}$ E2 for $48 \mathrm{~h}$ also had no significant effect on ESR1 mRNA levels (Fig. 4B), indicating that P4 + E2 was no longer effective in preventing culture-induced increase in ESR1 mRNA abundance compared to fresh tissue.

Similarly, stretch applied to myometrial strips for $48 \mathrm{~h}$ had no effect PTGS2 mRNA expression (Fig. 4C). Stretch applied in the presence of P4 + E2 likewise had no effect (Fig. 4D). Thus, the P4 + E2 treatment no longer exacerbated the increase in PTGS2 mRNA abundance that occurred after $48 \mathrm{~h}$ in vitro.

Applying stretch to myometrial strips for $48 \mathrm{~h}$ had no effect on OXTR expression (Fig. 4E). Stretch applied in the presence of $500 \mathrm{nM} \mathrm{P} 4+400 \mathrm{nM}$ E2 also had no effect on OXTR mRNA abundance after $48 \mathrm{~h}$ culture (Fig. 4F).

\section{The effects of activating intracellular signalling pathways}

Relative abundance of ESR1, PTGS2 and OXTR mRNA was measured in myometrial tissues incubated for $48 \mathrm{~h}$ in the presence of 8 -Br-cAMP $(250 \mu \mathrm{M})$, PMA $(0.1,1.0 \mu \mathrm{M})$ or vehicle (DMSO).

Adding $250 \mu \mathrm{M} 8$-Br-cAMP to the culture media had no effect on ESR1 mRNA expression (Fig. 5A). Similarly, supplementing media with 0.1 or $1.0 \mu \mathrm{M}$ PMA, a protein kinase C (PKC) activator, had no effect on ESR1 mRNA levels (Fig. 5B).

Adding $250 \mu \mathrm{M} 8$-Br-cAMP had no effect on PTGS2 mRNA abundance (Fig. 5C), but supplementing the culture media with $1.0 \mu \mathrm{M}$ PMA increased $P T G S 2$ expression significantly ( $P=0.047$ ) (Fig. 5D).

Adding $250 \mu \mathrm{M} 8$-Br-cAMP to the culture media had no significant effect on OXTR mRNA abundance after $48 \mathrm{~h}$ of culture (Fig. 5E). OXTR mRNA abundance was significantly increased in response to $1.0 \mu \mathrm{M}$ PMA $(P=0.0099)$ (Fig. 5F).

\section{The effect of NF-KB Inhibitors}

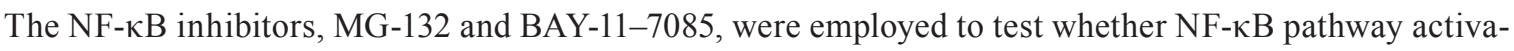
tion was involved in the gene expression changes induced by the in vitro conditions.

Incubating myometrial samples with $0,2,5$ or $10 \mu \mathrm{M}$ MG-132 or BAY-11-7085 individually or in combination (10 $\mu \mathrm{M}$ each) had no effect on ESR1 mRNA abundance (Fig. 6A-6C).

Neither inhibitor affected culture-induced changes in PTGS2 mRNA abundance (Fig. 6D and 6E), nor was PTGS2 mRNA abundance affected by a combination of the two compounds (Fig. 6F).

Similarly, supplementing culture media with MG-132 or BAY-11-7085 had no effect on OXTR mRNA abundance following $48 \mathrm{~h}$ of culture (Fig. $6 \mathrm{G}$ and $6 \mathrm{H}$ ), and OXTR mRNA abundance was not affected by a combination of the two compounds (Fig. 6I). 

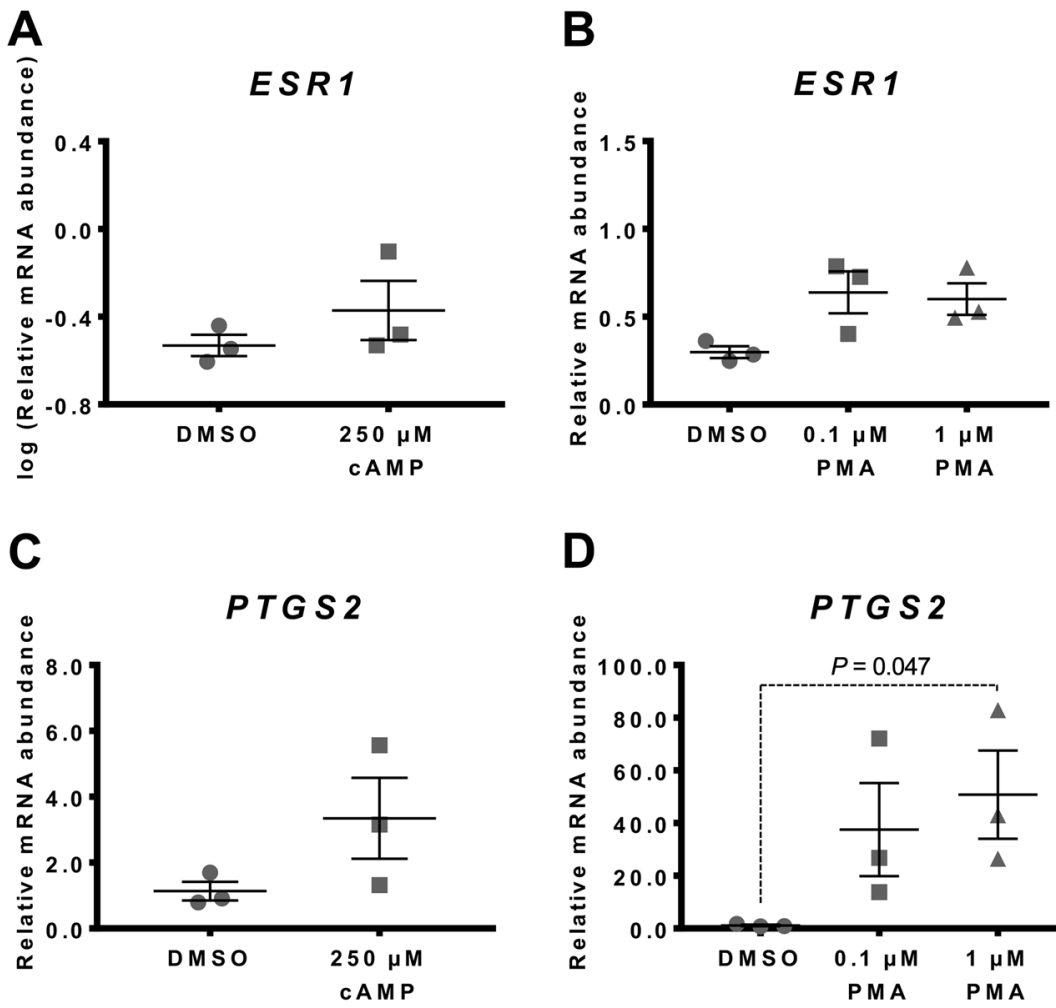

D
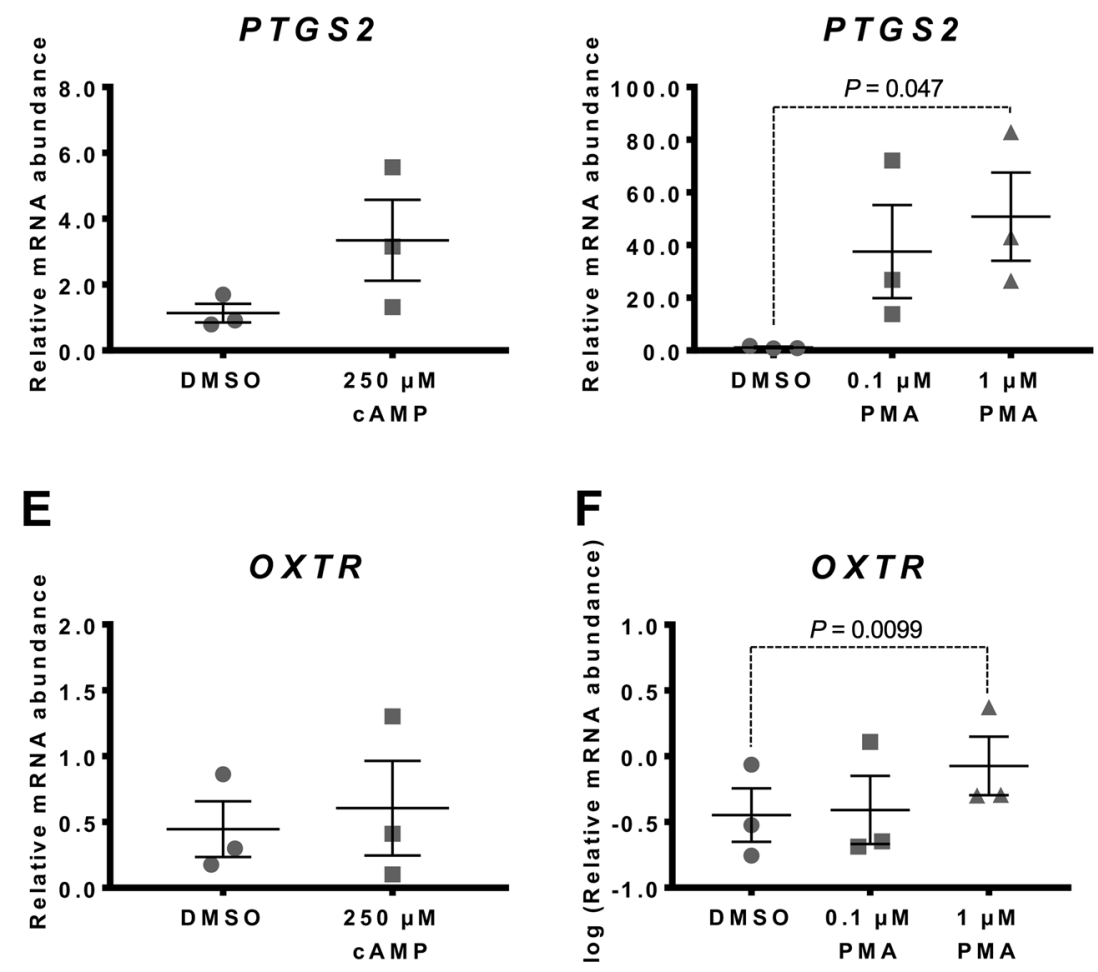

Fig. 5. Effect of cAMP and PMA on culture-induced changes in ESR1, PTGS2 and OXTR mRNA in vitro. Relative mRNA abundance of ESR1, PTGS2 and OXTR was measured in term non-laboring myometrial tissue samples $(n=3)$ following $48 \mathrm{~h}$ incubation in the presence of 8 -Br-cAMP $(250 \mu \mathrm{M})$ or PMA $(0.1$ and $1.0 \mu \mathrm{M})$, and expressed relative to Alien reference. (A) Effect of 8-Br-cAMP on ESR1 mRNA abundance. (B) Effect of PMA on ESR1 mRNA abundance. (C) Effect of 8-Br-cAMP on PTGS2 mRNA abundance. (D) Effect of PMA on PTGS2 mRNA abundance. (E) Effect of 8-Br-cAMP on OXTR mRNA abundance. (F) Effect of PMA on OXTR mRNA abundance. Data was checked for normality (ShapiroWilk normality test) and if necessary was logarithmically transformed to approach normal distribution (Shapiro-Wilk normality test). 8-Br-cAMP data was analysed using paired t-test, whilst 1-way ANOVA with multiple comparisons (Dunnett) was used to analyse PMA data. Data are mean \pm S.E.M.

\section{Discussion}

In the context of human parturition, in vitro models such as myometrial cell lines and ex situ tissues have been an important tool for investigating the maintenance of uterine quiescence and the mechanisms by which the myometrium transforms to an actively contracting organ at labor. This study examined whether 
A

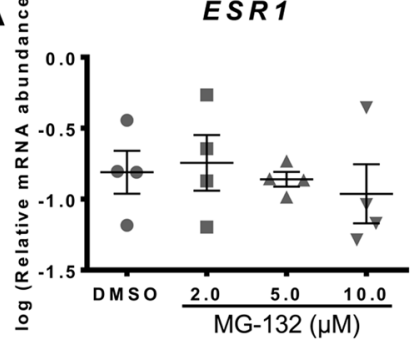

D
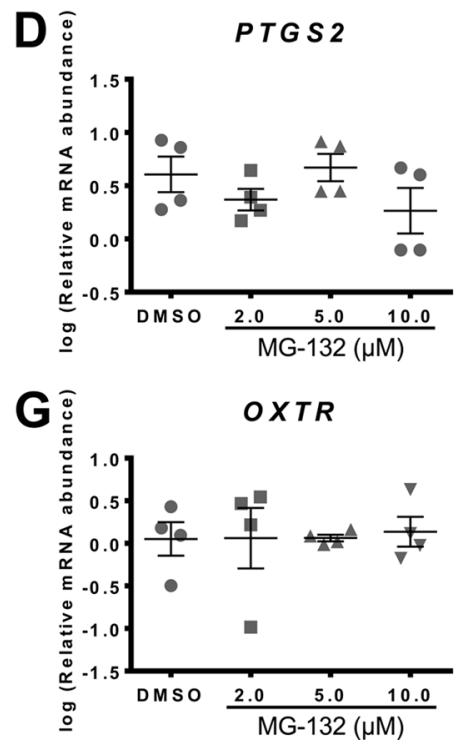

B

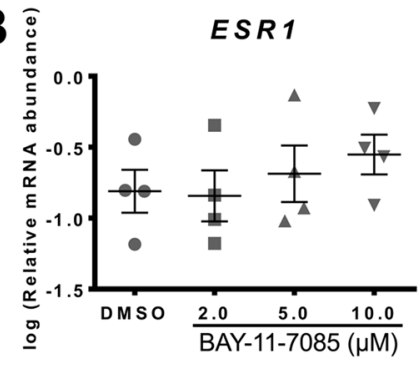

E

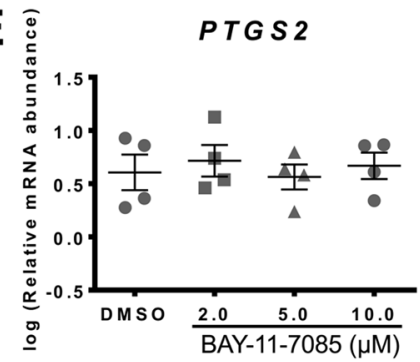

$\mathbf{H}$

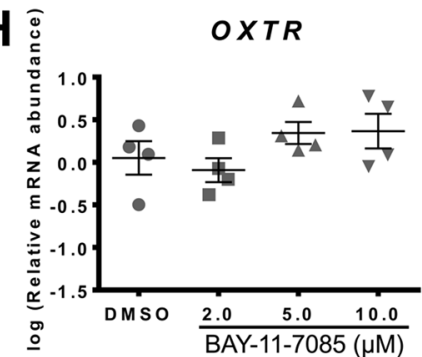

C

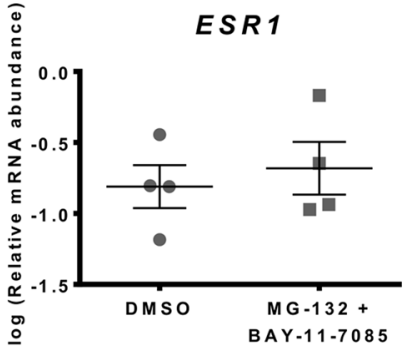

$\mathbf{F}$

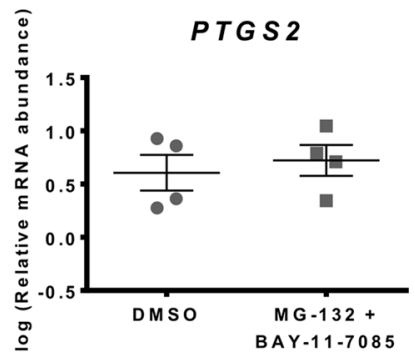

I

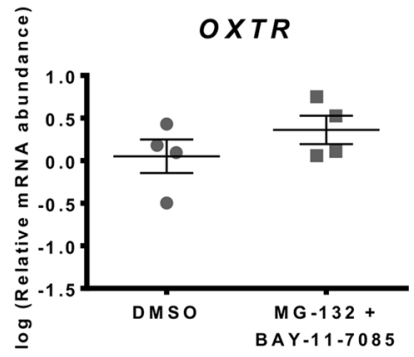

Fig. 6. Effect of NF- $\mathrm{KB}$ inhibitors, MG-132 and BAY-11-7085, on culture-induced changes in ESR1, PTGS2 and OXTR mRNA in vitro. Relative mRNA abundance of ESR1, PTGS2 and OXTR was measured in term nonlaboring myometrial samples $(n=4)$ following $48 \mathrm{~h}$ incubation in the presence of different NF- $\kappa \mathrm{B}$ inhibitors, and expressed relative to Alien reference RNA. (A) Effect of MG-132 on ESR1 mRNA abundance. (B) Effect of BAY-11-7085 on ESR1 mRNA abundance. (C) Effect of MG-132 and BAY-11-7085 on ESR1 mRNA abundance. (D) Effect of MG-132 on PTGS2 mRNA abundance. (E) Effect of BAY-11-7085 on PTGS2 mRNA abundance. (F) Effect of MG-132 and BAY-11-7085 on PTGS2 mRNA abundance. (G) Effect of MG-132 on OXTR mRNA abundance. (H) Effect of BAY-11-7085 on OXTR mRNA abundance. (I) Effect of MG-132 and BAY-11-7085 on OXTR mRNA abundance. Data was checked for normality (Shapiro-Wilk normality test) and if necessary was logarithmically transformed to approach normal distribution (Shapiro-Wilk normality test). MG-132 and BAY-11-7085 data was analysed by 1-way ANOVA with multiple comparisons (Dunnett). MG-132 + BAY-11-7085 data was analysed using paired t-test. Data are mean \pm S.E.M.

non-laboring myometrial tissues and strips undergo changes in culture that are consistent with transition to a pro-contractile, laboring phenotype. We determined gene expression changes as quantitative assessment of mRNA in preference to semi-quantitative estimates of protein levels by Western blot (30). Notably, recent studies examining protein profiles in mammalian cells have found that transcription, not translation, chiefly determines protein abundance (31), and that during periods of dynamic change, such as that occurring during phenotype transition, changes in mRNA abundance play a particularly dominant role in controlling changes in protein levels (32).

Here we showed that the abundance of both ESR1 and PTGS2 mRNAs was significantly increased after $48 \mathrm{~h}$ of culture of myometrial tissues (Fig. 1A and 1B). Our group previously reported that ESR1 expression increased in the myometrium with the onset of labor $(8,9)$. PTGS2 expression was also reported to increase in the human myometrium with labor $(14,17)$. Our observation that ESR1 and PTGS2 mRNA abundance increase 
during culture is thus consistent with the possibility that the myometrium has been transitioning to a laboring state in vitro. Moreover, OXTR expression was high in term non-laboring myometrium and significantly decreased after $48 \mathrm{~h}$ incubation (Fig. 1C). As shown previously, OXTR mRNA abundance increases in uterine tissue after 37 weeks of gestation (10) and there is an apparent fall in OXTR expression in advanced labor (11-13). Chan Y.W. et al. (14) characterized the human myometrial transcriptome during the transition from term, not-in-labor to in-labor state and confirmed that OXTR mRNA expression decreased with labor (14). Therefore, our observation that OXTR expression spontaneously declines during culture further supports a transition toward a laboring phenotype in vitro.

Performing in vitro experiments using myometrium that is in a state of flux is not ideal and raises the possibility that the relevant literature may contain findings reported for non-laboring tissue were in fact obtained with myometrium transitioning to a laboring phenotype. To address this problem we sought to identify culture conditions that could be implemented to prevent culture-induced changes in ESR1, PTGS2 and OXTR expression, which are markers of the pro-contractile transformation. We examined whether the presence of CSS (5\%) in the media affected the culture-induced changes of ESR1, PTGS2 and OXTR in myometrium (Fig. 2). Supplementing media with serum is common practice during in vitro culture, however, our results indicate that supplementing with serum alone is not sufficient to prevent culture-induced changes in these key myometrial genes.

The balance between progesterone and estrogen plays a key role in transformation of the myometrium from the quiescent to a contractile state. Progesterone maintains pregnancy by promoting myometrial quiescence $(3,33)$, while estrogen is considered a principal endocrine factor responsible for instigating myometrial activation $(1-3,8)$. Both progesterone and estrogen maternal plasma levels are high during human pregnancy and remain elevated during parturition $(4-7,34)$. Previous studies have shown that the interaction between progesterone and progesterone receptor B (PR-B) suppresses ESR1 expression, thereby rendering the myometrium refractory to circulating estrogen $(8,35)$. With advancing gestation, however, progesterone receptor A (PR-A) expression increases, which in turn represses the transcriptional activity of PR-B, and as a result the PR-Bmediated inhibition of ESRI expression is withdrawn $(8,35)$. Once myometrial tissue is removed from in vivo environment and cultured in vitro, the high plasma levels of progesterone and estrogen are no longer present, thereby removing the functional link between progesterone and estrogen (8), which could possibly account for the observed culture-induced changes in ESR1, PTGS2 and OXTR expression (Fig. 1). Consistent with the existing literature $(36,37)$, we found that supplementing media with $500 \mathrm{nM} \mathrm{P} 4$ prevented the culture-induced up-regulation of ESR1 mRNA abundance (Fig. 3A) over 48 h. Further, ESR1 expression remained repressed when $500 \mathrm{nM}$ P4 was administered in combination with $400 \mathrm{nM}$ E2. While culture-induced up-regulation of ESR1 expression was prevented by $500 \mathrm{nM} \mathrm{P} 4, \mathrm{P} 4$ alone was unable to prevent the culture-induced increase in PTGS2 expression in vitro. It was anticipated that $\mathrm{P} 4$ alone would prevent the culture-induced increase in PTGS2 expression based on previous reports that $\mathrm{P} 4$ inhibits PTGS2 expression in myometrial cells via direct interaction of the progesterone receptor (PR) with NF- $\mathrm{\kappa B}$ p65, as well as by progesterone-induced expression

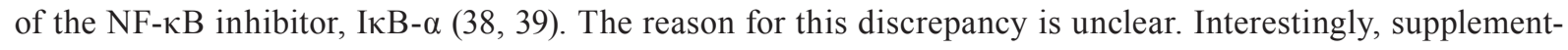
ing media with P4 + E2 significantly increased PTGS2 mRNA abundance beyond the level of culture-induced increase in the absence of steroids (Fig. 1B and 3B).

A study using immortalized human myocytes reported that progesterone binding to its receptor up-regulated zinc finger E-box binding homeobox protein 1 and suppressed miR-200b/429, which led to down-regulated OXTR expression (40). We found that supplementing media with P4 alone was unable to prevent the culture-induced decline in OXTR expression during culture (Fig. 3C). Furthermore, it was anticipated that 
supplementing media with E2 would increase OXTR expression, as our group has previously shown that E2 treatment for $6 \mathrm{~h}$ significantly increased OXTR expression in myometrial tissue (9). Possibly, E2 was unable to up-regulate OXTR expression in the present study due to being administered in combination with P4.

In normal pregnancy the uterus increases several-fold in size by both hyperplasia and hypertrophy to accommodate the growing fetus and placenta $(41,42)$. Previous studies in the sheep, rat and wallaby have shown that stretch increased PTGS2 and OXTR expression, whereas ESR1 expression was not significantly affected (43-45). In humans, uterine wall tension was found to increase across gestation, as calculated by measuring uterine wall thickness and intrauterine pressure (46). Tension rose markedly beyond 30-weeks, and at 37-weeks ranged from approximately $10-75 \mathrm{kN} / \mathrm{m}^{2}$. This study examined stretch as a culture condition potentially affecting the in vitro changes in ESR1, PTGS2 or OXTR expression. We found that constant stretch, applied by means of attaching a hanging weight to tissue strips, did not influence the changes in ESR1, PTGS2 or OXTR mRNA levels (Figs. 1 and 4). This is at variance with previous reports that stretch has up-regulated PTGS2 and OXTR expression in the uterus; however, it should be noted that those studies were performed in animals (43-45). It should also be noted that maximum tension applied in our assay $\left(3 \mathrm{~g} ; 7.35 \mathrm{kN} / \mathrm{m}^{2}\right)$ was slightly below the range calculated by Sokolowski et al. at 37-weeks (46) $\left(10-75 \mathrm{kN} / \mathrm{m}^{2}\right)$. Applying tension $>7.35 \mathrm{kN} / \mathrm{m}^{2}$ in preliminary experiments was found to cause muscle tearing in our system, whereas $7.35 \mathrm{kN} / \mathrm{m}^{2}$ stretched the tissue strips sustainably for the $48 \mathrm{~h}$ culture period. It has been reported that in a P4-dominated endocrine environment, moderate stretch maintains relaxation and quiescence; however, in the absence of P4 or excessive stretch, the uterus contracts $(41,42)$. Interestingly, although stretch did not directly affect the culture-induced changes in ESR1, PTGS2 or OXTR expression, it prevented steroids (P4 + E2) from blocking the culture-induced increase in ESR1 mRNA abundance, and prevented steroids from increasing PTGS2 mRNA abundance (beyond the increase in vitro).

It is well documented that the cAMP signalling pathway is up-regulated in the human myometrium throughout pregnancy to maintain uterine quiescence (47-49). Supplementing media with a cAMP analogue 8-Br-cAMP failed to prevent culture-induced changes in ESR1, PTGS2 or OXTR mRNA abundance. We also examined effects of PMA, a pro-contractile agent, on ESR1, PTGS2 and OXTR expression. PMA activates PKC, which stimulates signalling pathways mediated by extracellular signal-regulated kinase (ERK) and NF$\kappa \mathrm{B}$, both involved in labor $(50,51)$. Furthermore, PKC activity is crucial for oxytocin-stimulated myometrial contractions (52). PMA was effective in modulating expression of both PTGS2 and OXTR, but had no effect on ESR1. As expected for a pro-contractile agent, PMA up-regulated PTGS2 expression in vitro, which was consistent with augmenting the transition toward a laboring phenotype. Interestingly, PMA prevented the cultureinduced decline in $O X T R$ expression. Actions of PMA on OXTR were therefore consistent with preserving the term not-in-labor phenotype, which is characterised by high $O X T R$ expression.

Previous studies have shown that labor is an inflammatory process associated with increased production of pro-inflammatory mediators, increased expression of PTGS2 mRNAs and increased NF- $\mathrm{BB}$ activity (17, 53-55). Supplementing media with NF- $\mathrm{BB}$ inhibitors such as MG-132 or BAY-11-7085, therefore, represented a feasible means of preventing culture-induced changes in ESR1, PTGS2 or OXTR expression. These inhibitors, added either separately or in combination, had no effect on ESR1, PTGS2 and OXTR mRNA abundance. This argues against the possibility that our culture conditions activated NFKB-dependent inflammatory pathways causing transition to a laboring phenotype. Nevertheless, preliminary data using two NF- $\mathrm{B}$ inhibitors do not prevent the need for further detailed studies to fully explore the effects of various culture conditions on inflammatory pathway activation and the associated functional consequences in myometrial explant systems. 


\section{Conclusion}

Term non-laboring human myometrial tissue undergoes culture-induced changes in expression of ESR1, PTGS2 and OXTR that are consistent with transitioning toward a laboring phenotype. Culture-induced transition toward a laboring phenotype calls for caution as to whether non-laboring myometrial biopsies remain representative of non-laboring myometrial tissue throughout the course of experiments, and as such may cast doubt on findings gleaned from not-in-labor tissue. Through examining various culture conditions, we found progesterone blocked the culture-induced increase in ESR1, but failed to prevent culture-induced increase in PTGS2. Culture-induced decline in OXTR expression was prevented by supplementing media with PMA, however, this was concurrent with further stimulation of PGTS2 expression toward a laboring phenotype. Culture-induced increase of PTGS2 expression in vitro was not counteracted by any of the treatments examined, including supplementation with NF- $\mathrm{kB}$ inhibitors. Additional studies are warranted to determine appropriate culture conditions that prevent the changes of key myometrial genes in vitro, thereby providing a stable platform on which to investigate the regulation of myometrial biology. Before that, in vitro studies using myometrial cells or tissues should be interpreted cautiously regarding the relevance to myometrial regulation during pregnancy and labor in vivo.

\section{Author Contributions}

Conceived and designed experiments: MI, TZ, JWP. Sample collection: MI. Performed experiments: MI, JWP. Data analysis: MI, JWP. Assisted with data analysis: TZ, TB. Provided reagents and materials: TZ, JWP. Manuscript Writing: MI, JWP. Manuscript Editing: TB, TZ.

\section{Ethical approval}

All studies involving human participants were approved by the Hunter and New England Area Human Research Ethics Committee, adhering to guidelines of the University of Newcastle and John Hunter Hospital, Newcastle, Australia (02/06/12/3.13). All participants gave informed written consent.

\section{Conflict of Interest}

The Author(s) declare(s) that there is no conflict of interest.

\section{Funding}

This work was supported by School of Medicine and Public Health Research Training Scheme (RTS). Facilities and infrastructure were provided by the University of Newcastle and Hunter Medical Research Institute (HMRI).

\section{Acknowledgments}

The authors wish to thank the obstetricians from the John Hunter Hospital, NSW, our research midwife, Anne Wright, and the research participants who donated samples toward this study. 


\section{References}

1. Matthews SG, Gibb W, Lye SJ, Challis JRG. Endocrine and paracrine regulation of birth at term and preterm. Endocr Rev. 2000; 21(5): 514-50. [Medline]

2. Norwitz ER, Robinson JN, Challis JR. The control of labor. N Engl J Med. 1999; 341(9): 660-6. [Medline] [CrossRef]

3. Mesiano S. Myometrial progesterone responsiveness and the control of human parturition. J Soc Gynecol Investig. 2004; 11(4): 193-202. [Medline] [CrossRef]

4. Tulchinsky D, Hobel CJ, Yeager E, Marshall JR. Plasma estrone, estradiol, estriol, progesterone, and 17-hydroxyprogesterone in human pregnancy. I. Normal pregnancy. Am J Obstet Gynecol. 1972; 112(8): 1095-100. [Medline] [CrossRef]

5. Walsh SW, Stanczyk FZ, Novy MJ. Daily hormonal changes in the maternal, fetal, and amniotic fluid compartments before parturition in a primate species. J Clin Endocrinol Metab. 1984; 58(4): 629-39. [Medline] [CrossRef]

6. Smith R, Smith JI, Shen X, Engel PJ, Bowman ME, McGrath SA, Bisits AM, McElduff P, Giles WB, Smith DW. Patterns of plasma corticotropin-releasing hormone, progesterone, estradiol, and estriol change and the onset of human labor. J Clin Endocrinol Metab. 2009; 94(6): 2066-74. [Medline] [CrossRef]

7. De Hertogh R, Thomas K, Bietlot Y, Vanderheyden I, Ferin J. Plasma levels of unconjugated estrone, estradiol and estriol and of HCS throughout pregnancy in normal women. J Clin Endocrinol Metab. 1975; 40(1): 93-101. [Medline] [CrossRef]

8. Mesiano S, Chan EC, Fitter JT, Kwek K, Yeo G, Smith R. Progesterone withdrawal and estrogen activation in human parturition are coordinated by progesterone receptor A expression in the myometrium. J Clin Endocrinol Metab. 2002; 87(6): 2924-30. [Medline] [CrossRef]

9. Welsh T, Johnson M, Yi L, Tan H, Rahman R, Merlino A, Zakar T, Mesiano S. Estrogen receptor (ER) expression and function in the pregnant human myometrium: estradiol via ER $\alpha$ activates ERK1/2 signaling in term myometrium. J Endocrinol. 2012; 212(2): 227-38. [Medline] [CrossRef]

10. Wathes DC, Smith HF, Leung ST, Stevenson KR, Meier S, Jenkin G. Oxytocin receptor development in ovine uterus and cervix throughout pregnancy and at parturition as determined by in situ hybridization analysis. J Reprod Fertil. 1996; 106(1): 23-31. [Medline] [CrossRef]

11. Fuchs AR, Fuchs F, Husslein P, Soloff MS. Oxytocin receptors in the human uterus during pregnancy and parturition. Am J Obstet Gynecol. 1984; 150(6): 734-41. [Medline] [CrossRef]

12. Bossmar T, Akerlund M, Fantoni G, Szamatowicz J, Melin P, Maggi M. Receptors for and myometrial responses to oxytocin and vasopressin in preterm and term human pregnancy: effects of the oxytocin antagonist atosiban. Am J Obstet Gynecol. 1994; 171(6): 1634-42. [Medline] [CrossRef]

13. Rivera J, López Bernal A, Varney M, Watson SP. Inositol 1,4,5-trisphosphate and oxytocin binding in human myometrium. Endocrinology. 1990; 127(1): 155-62. [Medline] [CrossRef]

14. Chan YW, van den Berg HA, Moore JD, Quenby S, Blanks AM. Assessment of myometrial transcriptome changes associated with spontaneous human labour by high-throughput RNA-seq. Exp Physiol. 2014; 99(3): 510-24. [Medline] [CrossRef]

15. Kim SH, MacIntyre DA, Firmino Da Silva M, Blanks AM, Lee YS, Thornton S, Bennett PR, Terzidou V. Oxytocin activates NF- $\kappa$ B-mediated inflammatory pathways in human gestational tissues. Mol Cell Endocrinol. 2015; 403: 64-77. [Medline] [CrossRef]

16. Pont JN, McArdle CA, López Bernal A. Oxytocin-stimulated NFAT transcriptional activation in human myometrial cells. Mol Endocrinol. 2012; 26(10): 1743-56. [Medline] [CrossRef]

17. Astle S, Newton R, Thornton S, Vatish M, Slater DM. Expression and regulation of prostaglandin E synthase isoforms in human myometrium with labour. Mol Hum Reprod. 2007; 13(1): 69-75. [Medline] 
[CrossRef]

18. Hayflick L, Moorhead PS. The serial cultivation of human diploid cell strains. Exp Cell Res. 1961; 25: 585-621. [Medline] [CrossRef]

19. Bodnar AG, Ouellette M, Frolkis M, Holt SE, Chiu CP, Morin GB, Harley CB, Shay JW, Lichtsteiner $\mathrm{S}$, Wright WE. Extension of life-span by introduction of telomerase into normal human cells. Science. 1998; 279(5349): 349-52. [Medline] [CrossRef]

20. Perez-Reyes N, Halbert CL, Smith PP, Benditt EP, McDougall JK. Immortalization of primary human smooth muscle cells. Proc Natl Acad Sci USA. 1992; 89(4): 1224-8. [Medline] [CrossRef]

21. Qian J, Hendrix M, Larsen WJ, Dorn GW 2nd, Lessard JL. Establishment and characterization of a conditionally immortalized smooth muscle/myometrial-like cell line. Mol Reprod Dev. 1997; 47(3): 284-94. [Medline] [CrossRef]

22. Chapdelaine P, Kang J, Boucher-Kovalik S, Caron N, Tremblay JP, Fortier MA. Decidualization and maintenance of a functional prostaglandin system in human endometrial cell lines following transformation with SV40 large T antigen. Mol Hum Reprod. 2006; 12(5): 309-19. [Medline] [CrossRef]

23. Anderson L, Martin W, Higgins C, Nelson SM, Norman JE. The effect of progesterone on myometrial contractility, potassium channels, and tocolytic efficacy. Reprod Sci. 2009; 16(11): 1052-61. [Medline] [CrossRef]

24. Baumbach J, Shi SQ, Shi L, Balducci J, Coonrod DV, Garfield RE. Inhibition of uterine contractility with various tocolytics with and without progesterone: in vitro studies. Am J Obstet Gynecol. 2012; 206(3): 254.e1-5 [CrossRef]. [Medline]

25. Tyson EK, Smith R, Read M. Evidence that corticotropin-releasing hormone modulates myometrial contractility during human pregnancy. Endocrinology. 2009; 150(12): 5617-25. [Medline] [CrossRef]

26. Paul J, Maiti K, Read M, Hure A, Smith J, Chan EC, Smith R. Phasic phosphorylation of caldesmon and ERK 1/2 during contractions in human myometrium. PLoS One. 2011; 6(6): e21542. [Medline] [CrossRef]

27. Hudson CA, Heesom KJ, López Bernal A. Phasic contractions of isolated human myometrium are associated with Rho-kinase (ROCK)-dependent phosphorylation of myosin phosphatase-targeting subunit (MYPT1). Mol Hum Reprod. 2012; 18(5): 265-79. [Medline] [CrossRef]

28. Livak KJ, Schmittgen TD. Analysis of relative gene expression data using real-time quantitative PCR and the 2(-Delta Delta C(T)) Method. Methods. 2001; 25(4): 402-8. [Medline] [CrossRef]

29. Mosher AA, Rainey KJ, Bolstad SS, Lye SJ, Mitchell BF, Olson DM, Wood SL, Slater DM. Development and validation of primary human myometrial cell culture models to study pregnancy and labour. BMC Pregnancy Childbirth. 2013; 13(Suppl 1): S7. [Medline]

30. Taggart MJ, Arthur P, Zielnik B, Mitchell BF. Molecular pathways regulating contractility in rat uterus through late gestation and parturition. Am J Obstet Gynecol. 2012; 207(1): 76.e15-24. [Medline] [CrossRef]

31. Li JJ, Biggin MD. Gene expression. Statistics requantitates the central dogma. Science. 2015; 347(6226): 1066-7. [Medline] [CrossRef]

32. Jovanovic M, Rooney MS, Mertins P, Przybylski D, Chevrier N, Satija R, Rodriguez EH, Fields AP, Schwartz S, Raychowdhury R, Mumbach MR, Eisenhaure T, Rabani M, Gennert D, Lu D, Delorey T, Weissman JS, Carr SA, Hacohen N, Regev A. Immunogenetics. Dynamic profiling of the protein life cycle in response to pathogens. Science. 2015; 347(6226): 1259038. [Medline] [CrossRef]

33. Csapo A. Progesterone block. Am J Anat. 1956; 98(2): 273-91. [Medline] [CrossRef]

34. Boroditsky RS, Reyes FI, Winter JS, Faiman C. Maternal serum estrogen and progesterone concentrations preceding normal labor. Obstet Gynecol. 1978; 51(6): 686-91. [Medline]

35. Mesiano S, Welsh TN. Steroid hormone control of myometrial contractility and parturition. Semin Cell Dev Biol. 2007; 18(3): 321-31. [Medline] [CrossRef] 
36. Haluska GJ, West NB, Novy MJ, Brenner RM. Uterine estrogen receptors are increased by RU486 in late pregnant rhesus macaques but not after spontaneous labor. J Clin Endocrinol Metab. 1990; 70(1): 181-6. [Medline] [CrossRef]

37. Leavitt WW, Cobb AD, Takeda A. Progesterone-modulation of estrogen action: rapid down regulation of nuclear acceptor sites for the estrogen receptor. Adv Exp Med Biol. 1987; 230: 49-78. [Medline] [CrossRef]

38. Kalkhoven E, Wissink S, van der Saag PT, van der Burg B. Negative interaction between the RelA(p65) subunit of NF-kappaB and the progesterone receptor. J Biol Chem. 1996; 271(11): 6217-24. [Medline] [CrossRef]

39. Hardy DB, Janowski BA, Corey DR, Mendelson CR. Progesterone receptor plays a major antiinflammatory role in human myometrial cells by antagonism of nuclear factor-kappaB activation of cyclooxygenase 2 expression. Mol Endocrinol. 2006; 20(11): 2724-33. [Medline] [CrossRef]

40. Renthal NE, Chen CC, Williams KC, Gerard RD, Prange-Kiel J, Mendelson CR. miR-200 family and targets, ZEB1 and ZEB2, modulate uterine quiescence and contractility during pregnancy and labor. Proc Natl Acad Sci USA. 2010; 107(48): 20828-33. [Medline] [CrossRef]

41. Loudon JA, Sooranna SR, Bennett PR, Johnson MR. Mechanical stretch of human uterine smooth muscle cells increases IL-8 mRNA expression and peptide synthesis. Mol Hum Reprod. 2004; 10(12): 895-9. [Medline] [CrossRef]

42. Sooranna SR, Lee Y, Kim LU, Mohan AR, Bennett PR, Johnson MR. Mechanical stretch activates type 2 cyclooxygenase via activator protein-1 transcription factor in human myometrial cells. Mol Hum Reprod. 2004; 10(2): 109-13. [Medline] [CrossRef]

43. Ou CW, Chen ZQ, Qi S, Lye SJ. Expression and regulation of the messenger ribonucleic acid encoding the prostaglandin $\mathrm{F}(2 \mathrm{alpha}$ ) receptor in the rat myometrium during pregnancy and labor. Am J Obstet Gynecol. 2000; 182(4): 919-25. [Medline] [CrossRef]

44. Parry LJ, Bathgate RA. The role of oxytocin and regulation of uterine oxytocin receptors in pregnant marsupials. Exp Physiol. 2000; 85(Spec No): 91S-9S. [Medline] [CrossRef]

45. Wu WX, Ma XH, Yoshizato T, Shinozuka N, Nathanielsz PW. Differential expression of myometrial oxytocin receptor and prostaglandin $\mathrm{H}$ synthase 2, but not estrogen receptor alpha and heat shock protein 90 messenger ribonucleic acid in the gravid horn and nongravid horn in sheep during betamethasone-induced labor. Endocrinology. 1999; 140(12): 5712-8. [Medline]

46. Sokolowski P, Saison F, Giles W, McGrath S, Smith D, Smith J, Smith R. Human uterine wall tension trajectories and the onset of parturition. PLoS One. 2010; 5(6): e11037. [Medline] [CrossRef]

47. Europe-Finner GN, Phaneuf S, Watson SP, López Bernal A. Identification and expression of G-proteins in human myometrium: up-regulation of G alpha s in pregnancy. Endocrinology. 1993; 132(6): 2484-90. [Medline]

48. Europe-Finner GN, Phaneuf S, Tolkovsky AM, Watson SP, López Bernal A. Down-regulation of G alpha $\mathrm{s}$ in human myometrium in term and preterm labor: a mechanism for parturition. J Clin Endocrinol Metab. 1994; 79(6): 1835-9. [Medline]

49. López Bernal A, Europe-Finner GN, Phaneuf S, Watson SP. Preterm labour: a pharmacological challenge. Trends Pharmacol Sci. 1995; 16(4): 129-33. [Medline] [CrossRef]

50. Molnár M, Rigó J Jr., Romero R, Hertelendy F. Oxytocin activates mitogen-activated protein kinase and up-regulates cyclooxygenase-2 and prostaglandin production in human myometrial cells. Am J Obstet Gynecol. 1999; 181(1): 42-9. [Medline] [CrossRef]

51. Choi SJ, Oh S, Kim JH, Roh CR. Changes of nuclear factor kappa B (NF-kappaB), cyclooxygenase-2 (COX-2) and matrix metalloproteinase-9 (MMP-9) in human myometrium before and during term labor. Eur J Obstet Gynecol Reprod Biol. 2007; 132(2): 182-8. [Medline] [CrossRef]

52. Morrison JJ, Dearn SR, Smith SK, Ahmed A. Activation of protein kinase C is required for oxytocin- 
induced contractility in human pregnant myometrium. Hum Reprod. 1996; 11(10): 2285-90. [Medline] [CrossRef]

53. Allport VC, Pieber D, Slater DM, Newton R, White JO, Bennett PR. Human labour is associated with nuclear factor-kappaB activity which mediates cyclo-oxygenase-2 expression and is involved with the 'functional progesterone withdrawal'. Mol Hum Reprod. 2001; 7(6): 581-6. [Medline] [CrossRef]

54. Lindström TM, Bennett PR. The role of nuclear factor kappa B in human labour. Reproduction. 2005; 130(5): 569-81. [Medline] [CrossRef]

55. Osman I, Young A, Ledingham MA, Thomson AJ, Jordan F, Greer IA, Norman JE. Leukocyte density and pro-inflammatory cytokine expression in human fetal membranes, decidua, cervix and myometrium before and during labour at term. Mol Hum Reprod. 2003; 9(1): 41-5. [Medline] [CrossRef] 